\title{
CHARACTERIZATION AND MODELING SURFACE SOIL PHYSICOCHEMICAL PROPERTIES USING LANDSAT IMAGES: A CASE STUDY IN THE IRAQI KURDISTAN REGION
}

\author{
A. M. F. Al-Quraishi ${ }^{1, *}$, H. A. Sadiq ${ }^{2}$, J. P. Messina ${ }^{3}$ \\ ${ }^{1}$ Dept. of Environmental Engineering, College of Engineering, Knowledge University, Erbil 44001, Kurdistan Region, Iraq \\ - ayad.alquraishi@gmail.com, ayad.alquraishi@knowledge.edu.krd \\ ${ }^{2}$ Dept. of Soil and Water Sciences, College of Agriculture, Salahaddin University, Erbil 44003, Kurdistan Region, Iraq \\ - hawar.sadiq@su.edu.krd \\ ${ }^{3}$ Dept. of Geography, Environment, and Spatial Sciences, Michigan State University, East Lansing, Michigan 48823, United States \\ -jpm@msu.edu
}

KEY WORDS: Surface soil physicochemical properties, characterization, modelling, Landsat ETM+, GIS, Kurdistan, Iraq

\begin{abstract}
:
Quickly and accurately soil properties characterization is critical for many environmental and agricultural activities. This paper aimed at characterizing and modelling the surface soil physicochemical properties using soil laboratory analyses, Landsat-7 ETM+ images, statistical analyses, remote sensing and GIS techniques. A mosaic of two Landsat-7 ETM+ images and forty geo-referenced surface soil samples $(0-10 \mathrm{~cm})$ have been collected in 2012 from forty sites in the Iraqi Kurdistan region were used. Several physicochemical properties for the collected soil samples were estimated using laboratory analyses. In addition, the corresponding top-of-atmosphere (ToA) reflectance values, which extracted from the Landsat ETM+ images have been used. Statistical correlation and regression analyses using the SPSS were carried out to explore the most significant relationships among soil properties and the spectral bands of the ETM+ images. Predicted maps for the surface soil physicochemical characteristics were generated using ERDAS ER-Mapper. The study results revealed some significant relationships between the ETM+ images bands values and the studied soil properties. The strongest relationship was found to be between the air-dry soil moisture content (ADSMC) and the ETM+ images bands. Given a representative collection of field data, the methods presented offer a reliable set of tools for the rapid production of surface soil maps in arid environments.
\end{abstract}

\section{INTRODUCTION}

Remote Sensing utilizes electromagnetic radiation to determine properties of target features from a distance and has the advantages of extent, non-invasiveness, timeliness, and flexibility. It has already been extensively applied to many environment-related disciplines such as ecology, oceanography, climatology, geology, and agriculture. Soil is one of the most important components of agricultural production and can have a significant influence on crop yields and quality (Brussaard, et al., 2007, Cassman, 1999, Mausbach, et al., 1997, Fadhil, 2011, Wu et al, 2019; Al-Quraishi and Negm 2019). In-field soil data have long been used by agronomists to make decisions concerning crop management (Jensen, 1996, King et al., 2005).

At the present time, site-specific management systems and precision agriculture comprise a technique which reduces costs, optimizes crop yield, and enhances environmental protection. Precision farming promotes applying inputs only where necessary and with the minimum quantity of product necessary to achieve target yields (NRC, 1997). This kind of agricultural management needs both the spatial distribution of field deficiencies and target patch-spraying technologies.

The characterizing, mapping and modelling of physicochemical soil properties have become progressively automated due to advances in statistical software and improvements in computing performance. Spatial distribution, interpolation, and maps of soil characteristics have been produced by diverse methods including inverse distance calculations (Bregt et al., 1992), factorial kriging (Bocchi et al., 2000), or ordinary kriging (Lopez-Granados et al., 2002, Paz-Gonzalez et al., 2001). The spatial distribution of soil properties has also been calculated using reflectance measurements (Madeira Netto, 1996). Reflectance is a property resulting from the inherent spectral comportment of each soil element (mineral, organic and liquid component). Numerous studies have been estimated the effectiveness of land surface spectral differences for soil classification. Further, organic matter, moisture, mineral oxides, texture and surface conditions all impact soil reflectance when measured with a spectroradiometer (Henderson et al., 1992, Schulze et al., 1993, Stoner and Baumgardner, 1981).

Iraq has become a regionally significant importer and consumer of agricultural products, dominated by wheat and rice, vegetables, and fruits (Al-Quraishi et al 2019; Fadhil 2009; Wu et al 2018). Therefore, to encourage the local agricultural sectors, there is an increasing concern with land use planning. The basis of the agricultural planning is the knowledge of the soil physicochemical characteristics. As part of soil evaluation process, traditional soil analyses have played an important role in this regard. Traditional soil mapping approaches have mostly relied on ground-based surveys (Wu et al., 2018). Classical field surveys including soil sampling and laboratory analyses are time consuming and expensive, especially when mapping is being done at national, regional or global scales. Given the need for rapid agricultural planning at minimal costs, new techniques are being developed for obtaining appropriate high-quality soil information (Dobos et al. 2001). Digital soil mapping, which integrates secondary data sources into the mapping process, has been recognized as a means of exceeding the limits of traditional methodologies and refining the detail and spatial coverage of soil databases (Mulder et al. 2011, Wu et al., 2019; Fadhil 2013). Distinct from its cost efficiency, digital methodologies offer an impartial quantitative measure for prediction and a reduction in uncertainty compared to traditional methods employed in the region (Hengl et al., 2015).

Owing to these reasons, the techniques for the characterization of soil attributes by remote sensing have attracted substantial 
interest. They can be faster and cheaper than conventional methods, do not generate chemical residues and are nondestructive to the samples, allowing for the possibility of further analyses of the same sample (Nanni and Demattê, 2006; Al-Quraishi and Negm 2019). Currently, soil spectral characterization is commonly used owing to the availability of efficient and affordable equipment. Nevertheless, this technique has usually been applied to soil detection, classification and discrimination (Ben Dor and Banin, 1995), while little efforts has been directed towards the evaluation of soil chemical and physical attributes. There are significant differences between laboratory and orbital sensor data. However, there are few and non-conclusive experiments in the quantification of soil attributes by satellite sensors in this environment. Further, atmospheric interference and geometric fidelity issues complicate the interpretation of results (Guyot et al. 1996). Remotely sensed data can be gathered and analysed using specialized software and specified methods to extract soil characteristics and to support digital soil mapping (Ben-Dor et al., 2008, Slaymaker, 2001; Mustafa et al 2019; Almamalachy et al 2019). Finally, remote sensing techniques can facilitate mapping inaccessible areas by reducing the need for extensive time-consuming and costly field surveys.

The current study objectives were to predict, model, and map surface soil properties in several sites of the north of Iraq (particularly Kurdistan region and the Nineveh province) using field soil surveys, Landsat ETM+ images, statistical analyses, remote sensing and GIS techniques.

\section{STUDY AREA}

The study area (Figure 1) includes parts of Erbil, Duhok, Sulaimaniya governorates of the Iraqi Kurdistan, and some parts of Nineveh governorate at the north of Iraq. It comprises 13 districts: Hawler, Shaqlawa, Makhmour, Soran, Akre, Shekhan, Amedi, Mergasor, Pshdar, Choman, Rania, Dokan, and Koya and covers an area of about $22,546 \mathrm{~km}^{2}$. Its geographical location extends between lat. $37^{\circ}: 22^{\prime}: 27^{\prime \prime}$ to $35^{\circ}: 26^{\prime}: 19^{\prime \prime} \mathrm{N}$ and long. $43^{\circ}: 02^{\prime}: 43^{\prime \prime}$ to $45^{\circ}: 23^{\prime}: 13^{\prime \prime}$ E.

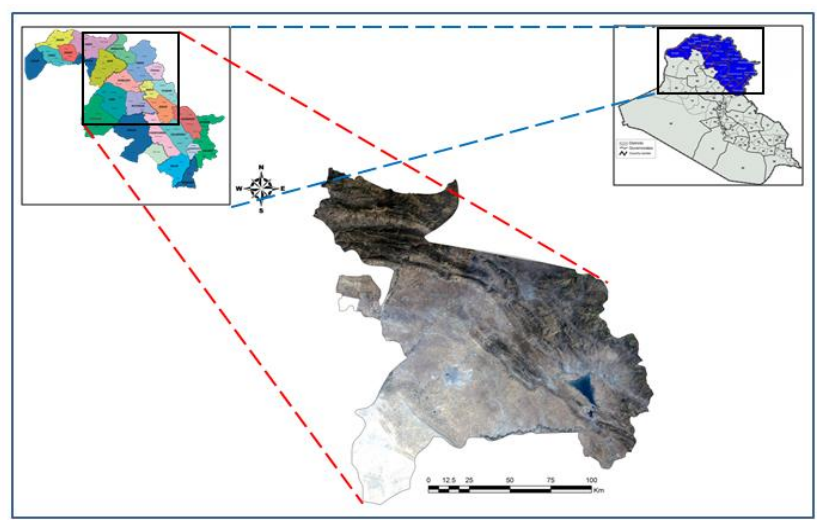

Figure 1. The location map of the study area and a Landsat RGB color composite 321 of 2012

\subsection{Physiography}

The Iraqi Kurdistan region of Iraq can be divided into three main physiographic zones, namely: (1) the northern range of the Zagros Mountains, (2) the central range of the border folds, and (3) the southern plains of the Tigris River. The north-northeastern part of the region is characterized by Zagros Mountains with heights up to $3600 \mathrm{~m}$ above sea level (asl). Snow coverage is common at high altitudes and vegetation cover is widespread, constituting both grasses and forests. A smoother morphology occurs in the central part, with the area characterized by an anticline/syncline system (Boccaletti and Dainelli 1982).

\subsection{Soil}

The soil in the mountainous areas of the Iraqi Kurdistan is shallow. In the valleys and plains areas, which are located in the south of study area, the soil is suitable for sustainable agriculture and crop production. It consists of chestnut soils, dark brown soils and black soils (Hameed, 2013). Soil texture in plain areas consists of loam clay sand, loam silt and silt clay, with an average depth of $140 \mathrm{~cm}$, and soil color varies between light yellow to dark brown. While, soil texture in mountainous areas is sandy clay, loam silt or loam clay sand, with an average depth of 130 $\mathrm{cm}$, and soil color is between brown and dark brown.

\subsection{Temperature}

Generally, the climate of the study area is characterized by extreme conditions. Which have large temperature differences between day and night and between winter and summer. In summer, the temperature reaches beyond $45 \mathrm{C}^{\circ}$ in daytime at the southern boundaries of the governorates. While, in the northern edges it goes down well below $20 \mathrm{C}^{\circ}$ at night. In winter, the daily temperature ranges from about $-15 \mathrm{C}^{\circ}$ to about $15 \mathrm{C}^{\circ}$. Accordingly, the climate of the study area has been classified as semi-arid continental.

\subsection{Rainfall}

The rainfall averages increase from the Southwest toward the Northeast direction. The annual averages ranging from $350 \mathrm{~mm}$ in the Erbil area to more than $1,100 \mathrm{~mm}$ in the high mountainous lands bordering Iran. The seasonal rainfall in the study area falls from September to June.

\section{MATERIALS AND METHODS}

\subsection{Methodology}

This study included field work, soil sampling, soil physical and chemical laboratory analyses, remotely sensed dataset collections, digital image processing, statistical analyses, and GIS analyses. Figure 2 shows the flowchart of methodology applied in this study.

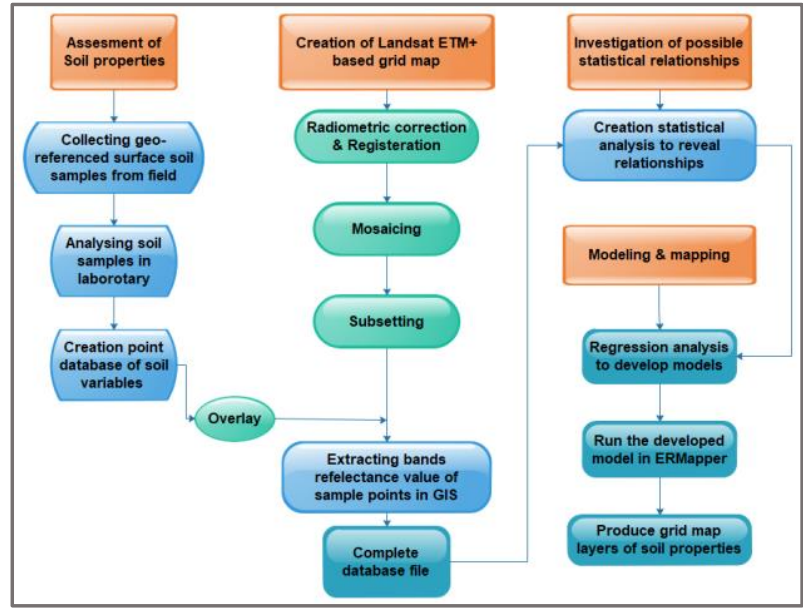

Figure 2. Methodology Flowchart 


\subsection{Field Work}

The field data were collected during field trips for 40 soil samples. The collected data included the soil status in general, topography, soil toughness, rock presence, slope and species and types of growing plants. All locations of the soil samples were photographed. The field data included a general survey of the entire study area, and the soils samples were used for both satellite data feature interpretation and spectral analyses.

\subsection{Soil Sampling}

The 40 geo-referenced soil samples were collected in May 2013 from the soil surface layer $(0-15 \mathrm{~cm})$ at thirteen administrative districts in the Erbil, Duhok, Sulaimaniya, and Nineveh in the north of Iraq (Figure 3). For each location; the geographical information (latitude, longitude, and elevation) were gathered in situ using a GPS handy device (Garmin etrux 20). All collected soil samples were air-dried, ground, and sieved through a $2 \mathrm{~mm}$ sieve to ensure mixture homogeneity for analyses. Several physical and chemical laboratory analyses were conducted for all the soil samples.

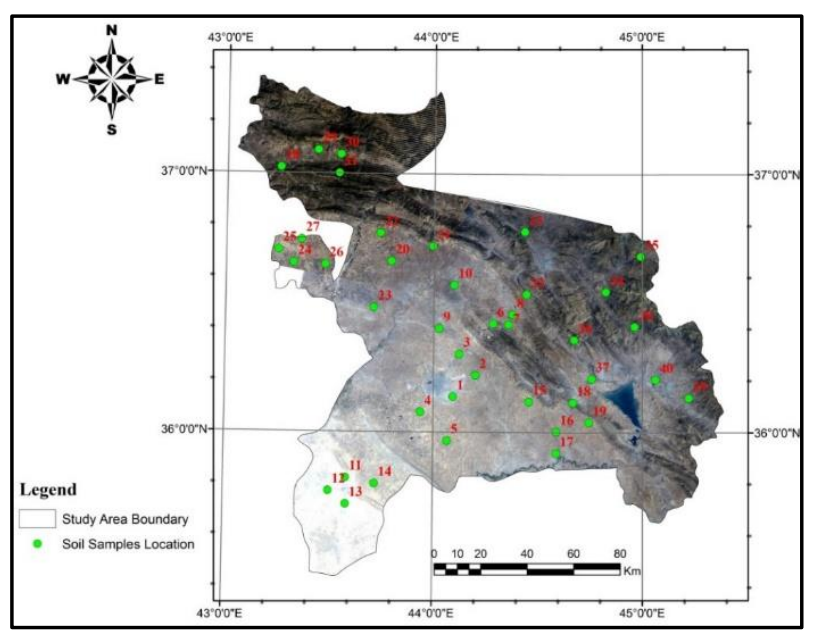

Figure 3. The map of the soil samples locations at the study area

\subsection{Laboratory Works}

Several physical and chemical soil laboratory analyses were conducted for the forty soil samples and included particle size distribution (percentage of each of sand, silt, and clay), air-dry soil moisture content (ADSMC), soil bulk density (BD). Chemical analyses included soil $\mathrm{pH}$, electrical conductivity (Ec), Soil organic matter $(\mathrm{OM})$, total calcium carbonate $\left(\mathrm{CaCO}_{3}\right)$, Cation Exchange Capacity (CEC), Available Phosphorous $\left(\mathrm{P}^{+3}\right)$, Extractable Sodium (Na+), Extractable Calcium and Magnesium $\left(\mathrm{Ca}^{+2}, \mathrm{Mg}^{+2}\right)$, Total Iron Oxides $\left(\mathrm{Fe}_{2} \mathrm{O}_{3}\right)$, Gypsum content $\left(\mathrm{CaSO}_{4} \cdot 2 \mathrm{H}_{2} \mathrm{O}\right)$.

\subsection{Remotely Sensed Dataset}

A mosaic of two Landsat-7 ETM+ images (without the Panchromatic band) were used for this study (path 169/row 35) and (path 170/row 34), dated July 07, 2012 and Aug 14, 2012, respectively. The two images with a spatial resolution of 30 meters were downloaded from (glovis.usgs.gov) in geoTIFF format. The two images were free of clouds and both were SLC.off type images. The images were radiometrically corrected using a model working with the ENVI version 4.8 for gap-filling the SLC-off data. A mosaic from the two images was created using ERDAS imagine. A mosaic of two Terra ASTER Digital Elevation Model (DEM) scenes was also created. The ASTER DEM dataset was downloaded from (asterweb.jpl.nasa.gov/).

\subsection{Statistical Analyses}

The statistical correlation coefficients were computed for the study variables such as soil samples properties and the ETM+ bands reflectance. The SPSS ver. 25 and multivariable statistics were employed to perform correlations and regression analyses. More than one independent variable was included in the regression analyses to minimize standard error as Escadafal and Huete, (1991) have indicated. In the regression analyses, values of the physicochemical properties of the studied soils were included as dependent variables, while the ETM+ bands reflectance values have been used as independent variables. Selection of the soil properties for regression analyses based on significance of their correlation with the values of the ETM+ bands reflectance.

\subsection{Soil Properties Modeling}

The study investigated the potential relationships between the properties of surface soil and their spectral values (ToA) with the aid of statistical correlation (Pearson) analysis, and then the significant relationships found were modelled with linear regression. The study employed for the regression calculations used only the strongly significant relationships (positive or negative) to develop reliable models. Ten linear regression sets were selected to develop ten distinct models to predict each of $\mathrm{BD}, \mathrm{ADSMC}, \mathrm{Na}, \mathrm{CaSO}_{3}, \mathrm{P}, \mathrm{Fe}_{2} \mathrm{O}_{3}, \mathrm{CEC}, \mathrm{CaCO}_{3}$, Clay, and Silt. The ten resultant regression equations were employed to produce predicted grid images for soil properties. The generated grid images then transferred into the ArcMap for processing, calculating statistics and to categorize using the natural breaks classification method.

\section{RESULTS AND DISCUSSION}

\subsection{The Statistical Analyses}

Results are summarized in Table 2, which shows the statistical correlations (Correlation Coefficient " $r$ ") and their significance among the soil properties and the corresponding reflectance in the seven bands of the Landsat ETM+ images.

\subsubsection{Statistical Analyses for Surface Soil Physical Properties Vs the ETM+ Bands}

Results of the statistical analyses revealed several significant correlations (Table 1) among the Landsat ETM+ bands and some of the surface soil properties. Significant negative relationships were found between each of the Landsat ETM+ bands, particularly B2, B3, B4, B5, and B7 with the soil bulk density by $(r=-0.374),(r=-0.389),(r=-0.364),(r=-0.335)$ and $(r=-0.389)$, respectively. Rasih et al., 1992 indicated that the increase in bulk density causes an increase in soil reflectance but this applies for soils, which do not have a dominant color or have a light color. In this study, surface soil samples were collected from some sites, which have very compacted, and hard soils or had bulk density values very close to the values of real density of soils characterized by black to dark-brown colors. Those soil characteristics caused a decrease in their soil spectral reflectance in general. Generally, those soils with high bulk density and dark colors were mostly located in the mountainous areas of the study area. 
Table 1. The correlation coefficients values and significance among the surface soil properties and the Landsat ETM+ bands reflectance

\begin{tabular}{|c|c|c|c|}
\hline & B1 & B2 & B3 \\
\hline $\mathrm{BD}$ & -.310 & $-.374(*)$ & $-.389(*)$ \\
\hline ADSMC & $-.553(* *)$ & $-.512(* *)$ & $-.495(* *)$ \\
\hline Clay & $-.400(*)$ & $-.434(* *)$ & $-.454(* *)$ \\
\hline Silt & .310 & $.409(* *)$ & $.422(* *)$ \\
\hline Sand & .064 & .019 & .024 \\
\hline $\mathrm{Na}$ & $.450(* *)$ & $.363(*)$ & $.348(*)$ \\
\hline $\mathrm{P}$ & -.129 & -.200 & -.241 \\
\hline $\mathrm{Cl}$ & .235 & .232 & .222 \\
\hline $\mathrm{Mg}$ & -.068 & -.113 & -.098 \\
\hline $\mathrm{Ca}$ & .244 & .203 & .192 \\
\hline $\mathrm{CaCO}_{3}$ & $.446(* *)$ & $.424(* *)$ & $.425(* *)$ \\
\hline $\mathrm{CaSO}_{4}$ & $-.424(* *)$ & $-.412(* *)$ & $-.395(*)$ \\
\hline $\mathrm{Fe}_{2} \mathrm{O}_{3}$ & $-.392(*)$ & $-.356(*)$ & $-.368(*)$ \\
\hline O.M. & $.358(*)$ & $.374(*)$ & $.372(*)$ \\
\hline CEC & $-.441(* *)$ & $-.436(* *)$ & $-.460(* *)$ \\
\hline $\mathrm{EC}$ & .221 & .167 & .163 \\
\hline $\mathrm{pH}$ & -.043 & -.022 & -.011 \\
\hline
\end{tabular}

Table 1. cont.

\begin{tabular}{|c|c|c|c|c|}
\hline & B4 & B5 & B6 & B7 \\
\hline $\mathrm{BD}$ & $-.364(*)$ & $-.335\left(^{*}\right)$ & -.296 & $-.389(*)$ \\
\hline ADSMC & $-.342(*)$ & $-.418(* *)$ & $-.380(*)$ & $-.507(* *)$ \\
\hline Clay & -.284 & $-.340\left(^{*}\right)$ & $-.342(*)$ & $-.376(*)$ \\
\hline Silt & $.492(* *)$ & $.400(*)$ & .036 & $.361\left(^{*}\right)$ \\
\hline Sand & -.145 & -.041 & .216 & .012 \\
\hline $\mathrm{Na}$ & .294 & $.354\left(^{*}\right)$ & .008 & $.362(*)$ \\
\hline $\mathrm{P}$ & -.218 & -.270 & $-.434(* *)$ & -.261 \\
\hline $\mathrm{Cl}$ & .176 & .148 & .257 & .183 \\
\hline $\mathrm{Mg}$ & -.122 & -.076 & .238 & -.066 \\
\hline $\mathrm{Ca}$ & .236 & .221 & .070 & .262 \\
\hline $\mathrm{CaCO}_{3}$ & $.494(* *)$ & $.517(* *)$ & .241 & $.495(* *)$ \\
\hline $\mathrm{CaSO}_{4}$ & $-.508(* *)$ & $-.441(* *)$ & .132 & $-.415(* *)$ \\
\hline $\mathrm{Fe}_{2} \mathrm{O}_{3}$ & -.222 & $-.313(*)$ & -.112 & $-.353(*)$ \\
\hline O.M. & $.393(*)$ & $.400\left(^{*}\right)$ & -.131 & $.413(* *)$ \\
\hline CEC & $-.338(*)$ & $-.389(*)$ & -.296 & $-.439(* *)$ \\
\hline $\mathrm{EC}$ & .167 & .242 & .250 & .256 \\
\hline $\mathrm{pH}$ & .040 & -.088 & .173 & -.034 \\
\hline
\end{tabular}

* Correlation is significant at the 0.05 level (2-tailed).

$* *$ Correlation is significant at the 0.01 level (2-tailed).

Alternatively, the results showed significant negative correlations between the soil reflectance at seven bands of the Landsat ETM+ image and the ADSMC by $(\mathrm{r}=-0.553),(\mathrm{r}=-0.512),(\mathrm{r}=-0.495)$, $(r=-0.342), \quad(r=-0.418), \quad(r=-0.380), \quad$ and $\quad(r=-0.507)$, respectively. The increase in soil moisture content causes decline in the reflectance values, this has also been reported by several researchers such as (Coleman and Montgomery, 1987 Horvath et al., 1984, Liu, et al., 2003). Additionally, significant negative correlations were observed between the reflectance values of Landsat ETM+ bands, mainly B1, B2, B3, B4, B5, and B7 with the percentage of soil clay particles by $(-0.400),(-0.434)$, ($0.454),(-0.340),(-0.342)$, and (-0.376), respectively. This result complies with results of (Gee, 1986, Dogan and Kilic, 2013). On the contrary, there were significant positive correlations between the percentage of soil silt particles and B2, B3, B4, B5, and B7 of the Landsat 7 ETM+ by (0.409), (0.422), (0.492), (0.400), and (0.361), respectively.

Montgomery, 1976 indicated in his study that soil silt particles were the most significant parameter in explaining spectral variation in soil texture. Likewise, (Coleman et al., 1993) studied the spectral differentiation of surface soils and soil properties with Landsat TM data and the Barnes Modular Multiband Radiometer (MMR). Consequently, they found significant correlations among remote sensing reflectance data in all seven Landsat bands and the soil texture particles. Additionally, some soils with lighter texture (sandy, loamy sands), and bright colors have substantial fine to medium quartz particles. Quartz has a high reflectance relative to soils with heavier textures (clayey) and which are usually characterized by dark colors as a result of the higher moisture content in those soils. These consequently appear to have low spectral reflectance (Ryan and Lewis, 2011).

\subsubsection{Statistical Analyses for Surface Soil Chemical Properties Vs the ETM+ Bands}

The results indicated that there were statistically significant positive correlations between the reflectance of Landsat 7 ETM+ bands, specifically B1, B2, B3, B5, and B7 with the sodium content in the soils by $(0.450),(0.363),(0.348),(0.354)$ and (0.362), respectively. Sabins, 1999 clarified that spectral reflectance of Halite $(\mathrm{NaCl})$, or rock salt was very high compared to the other types of salts. Results also found statistically significant negative correlations between the Landsat 7 ETM+ non-thermal bands (B1, B2, B3, B4, B5, and B7) and the gypsum (CaSO4.2H2O) content in the studied soils by $(-0.424),(-0.412)$, $(-0.395),(-0.508),-0.441$, and -0.415 , respectively. Hunt et al., 1971 reported that the reflectance of gypsum is low due to the inherent water content in the gypsum crystal structure.

A statistically significant negative correlation was also noticed between Band 6 of Landsat 7 ETM+ and available phosphorus content in the soils by $(-0.434)$. While significant negative correlations were detected between the ETM+ bands B1, B2, B3, $\mathrm{B} 5$, and $\mathrm{B} 7$ and the $\mathrm{Fe}_{2} \mathrm{O}_{3}$ in the studied soils by $(-0.392)$, (0.356), (-0.368), (-0.313), and (-0.353), respectively. Abrams and Hook, 1995 indicated that the iron oxide and iron hydroxides have specific absorption features that are located in the visible and near infrared (VNIR). Furthermore, Sabins 1997, reported that the reflectance spectra of iron minerals showed high red reflectance value around band three and low reflectance values around Band 1 of the Landsat TM images. In the current study, the iron oxides did not show a positive response to Band 3 (Red) of the ETM+. $\mathrm{Xu}$ et al., 2004 reported that the absorption features of iron oxide might be confounded in the presence of vegetation cover. Subsequently, the CEC and the non-thermal bands of the ETM+ (B1, B2, B3, B4, B5, and B7) had statistically significant negative correlations by (-0.441), (-0.436), (-0.460), (-0.338), (-0.389), and $(-0.439)$, respectively, in agreement with the results of Hussein, 2012.

On the other hand, the results highlighted to significant positive relationships between the $\mathrm{ETM}+$ bands $(\mathrm{B} 1, \mathrm{~B} 2, \mathrm{~B} 3, \mathrm{~B} 4, \mathrm{~B} 5$, and B7) and the $\mathrm{CaCO}_{3}$ content in the studied soils by (0.446), 
(0.424), (0.425), (0.494), (0.517), and (0.495), respectively. Those results are same to those found by Dogan and Kilic, 2013, Hussein, 2012. The reflectance values of Landsat Band 1 (Blue) has been used for the comparison of soil $\mathrm{CaCO} 3$ content, due to the fact that soil $\mathrm{CaCO}_{3}$ existence leads to has a slightly higher reflectance in Band 1 than reflectance at the other bands (Mix et al., 1995). The spectral reflectance of carbonate minerals in visible and near-infrared regions is not stable which is caused by absorption characteristics of the carbonate, as mentioned by Hexter, 1958, Adams, 1974, Hunt and Salisbury, 1971, Batjes, 1996.

The statistically significant positive correlations have been seen between the ETM+ bands (B1, B2, B3, B4, B5, and B7) and the soils OM content by $(0.358),(0.374),(0.372),(0.393),(0.400)$, and (0.413), respectively. Because of the OM has spectral reflectance through all visible, NIR, and shortwave IR regions, especially in visible region, it has become the most influential factor on spectral reflectance (Kristof et al., 1971). Baumgardner et al., 1970 reported that if the OM content in soils below than $2 \%$, it will have limited effect on the soil's reflectance.

\subsubsection{Statistical Analyses for the Soil Properties Vs the DEM}

The DEM statistical analyses results showed that there were significant correlations with each of Clay, $\mathrm{CaCO}_{3}, \mathrm{CEC}$, ADSMC, and BD by $(0.391 *),\left(-0.406^{* *}\right),(0.394 *),\left(0.718^{* *}\right)$, and $\left(0.314^{*}\right)$, respectively. In the region, with elevation increases, temperature decreases (Glickman, 2000) (Li, et al., 2005), contributing to an increase in soil moisture and vegetation cover along with increases in rainfall.

In Tables 2 and 3, large values of (r) and $\left(\mathrm{R}^{2}\right)$ showed statistical strong relationships and well-fitted models, respectively (SPSS, 2017). Table 3 showed that the highest value of $\left(R^{2}\right)$ was for the regression model for predicating the ADSMC by 0.480 , while the lowest $\left(\mathrm{R}^{2}\right)$ was 0.246 for the predicting model of soil $\mathrm{BD}$.

\subsection{Surface Soil Properties Modelling}

For modeling and mapping the surface soil properties in the study area, the statistical analyses have been employed using the SPSS to calculate statistical correlations among the soil variables (surface soil physicochemical properties) and the Landsat ETM+ images reflectance (ToA) values. To implement the statistical linear regression analysis, the soil variables selected were those showing strong correlations with the Landsat 7 ETM+ band's reflectance values. Accordingly, we developed ten regression models for determinations of the BD, ADSMC, $\mathrm{Na}, \mathrm{CaSO}_{3}, \mathrm{P}$, $\mathrm{Fe}_{2} \mathrm{O}_{3}, \mathrm{CEC}, \mathrm{CaCO}_{3}$, Clay, and Silt, whereas they had the highest coefficient of determination $\left(\mathrm{R}^{2}\right)$ values. Table 2 shows the regression equations (the well-fitted model), the dependent variables (surface soil properties), and the independent variables (Landsat ETM+ band's reflectance values, and the coefficient of determination $\left(\mathrm{R}^{2}\right)$.

\subsection{Predicting Regression-Based Surface Soil Properties Maps}

Soil properties modeling (mapping) is data driven and statistical methods and analyses with the aid of information technology to predicting properties of soil from soil samples, point observations and correlated with spatially detailed environmental variables (McBratney, et al., 2011, Boettinger, et al., 2010). Calculating statistical correlations and regression equations among the surface soil properties and Landsat-7 ETM+ bands ToA values enabled this study to modeling and mapping surface soil properties on a spatially obvious basis.
Table 2. The regression equations, which were used for soil properties modelling.

\begin{tabular}{|c|c|c|}
\hline $\begin{array}{l}\text { Soil } \\
\text { Properties }\end{array}$ & Regression Equations & $\mathrm{R}^{2}$ \\
\hline $\mathrm{BD}$ & $\begin{array}{l}\mathrm{Y}=5.190+[(2.023 * \mathrm{~B} 1)+(-1.930 * \mathrm{~B} 2)+ \\
(1.368 * \mathrm{~B} 3)+\left(-1.765^{*} \mathrm{~B} 4\right)+(1.586 * \mathrm{~B} 5)+ \\
(-0.010 * \mathrm{~B} 6)+(-2.170 * \mathrm{~B} 7)]\end{array}$ & 0.246 \\
\hline ADSMC & $\begin{array}{l}\mathrm{Y}=97.981+\left[\left(-46.262^{*} \mathrm{~B} 1\right)+(-\right. \\
\left.134.638^{*} \mathrm{~B} 2\right)+\left(96.516^{*} \mathrm{~B} 3\right)+(1.805 * \\
\mathrm{B} 4)+(12.960 * \mathrm{~B} 5)+(-0.269 * \mathrm{~B} 6)+(- \\
8.060 * \mathrm{~B} 7)]\end{array}$ & 0.480 \\
\hline $\mathrm{Na}$ & $\begin{array}{l}\mathrm{Y}=-4.471+[(375.157 * \mathrm{~B} 1)+(- \\
341.337 * \mathrm{~B} 2)+(186.949 * \mathrm{~B} 3)+(-35.218 \\
* \mathrm{~B} 4)+(59.827 * \mathrm{~B} 5)+(-0.048 * \mathrm{~B} 6)+(- \\
90.317 * \mathrm{~B} 7)]\end{array}$ & 0.255 \\
\hline $\mathrm{CaSO}_{4}$ & $\begin{array}{l}\mathrm{Y}=3.855+\left[\left(-9.446^{*} \mathrm{~B} 1\right)+\left(-15.543^{*} \mathrm{~B} 2\right)\right. \\
+\left(20.080^{*} \mathrm{~B} 3\right)+\left(-20.505^{*} \mathrm{~B} 4\right)+(- \\
\left.2.294 * \mathrm{~B} 5)+(0.021 * \mathrm{~B} 6)+\left(.055^{*} \mathrm{~B} 7\right)\right]\end{array}$ & 0.302 \\
\hline P & $\begin{array}{l}\mathrm{Y}=245.347+[(-18.730 * \mathrm{~B} 1)+( \\
535.731 * \mathrm{~B} 2)+(-314.492 * \mathrm{~B} 3)+(- \\
64.117 * \mathrm{~B} 4)+(-15.368 * \mathrm{~B} 5)+(- \\
0.692 * \mathrm{~B} 6)+(-29.965 * \mathrm{~B} 7)]\end{array}$ & 0.294 \\
\hline $\mathrm{Fe}_{2} \mathrm{O}_{3}$ & $\begin{array}{l}\mathrm{Y}=-7.560+[(-23.609 * \mathrm{~B} 1)+(65.688 * \mathrm{~B} 2) \\
+(-49.525 * \mathrm{~B} 3)+(12.027 * \mathrm{~B} 4)+(- \\
\left.3.548 * \mathrm{~B} 5)+\left(0.033^{*} \mathrm{~B} 6\right)+(3.340 * \mathrm{~B} 7)\right]\end{array}$ & 0.292 \\
\hline CEC & $\begin{array}{l}\mathrm{Y}=95.621+\left[\left(-314.498^{*} \mathrm{~B} 1\right)+(\right. \\
\left.854.609^{*} \mathrm{~B} 2\right)+\left(-582.313^{*} \mathrm{~B} 3\right)+( \\
\left.35.843^{*} \mathrm{~B} 4\right)+\left(-3.998^{*} \mathrm{~B} 5\right)+(-0.172 * \mathrm{~B} 6) \\
+(23.561 * \mathrm{~B} 7)]\end{array}$ & 0.345 \\
\hline $\mathrm{CaCO}_{3}$ & $\begin{array}{l}\mathrm{Y}=-335.318+[(248.895 * \mathrm{~B} 1)+(- \\
143.920 * \mathrm{~B} 2)+(-108.780 * \mathrm{~B} 3)+( \\
210.323 * \mathrm{~B} 4)+(34.168 * \mathrm{~B} 5)+(0.977 * \mathrm{~B} 6) \\
+(-5.135 * \mathrm{~B} 7)]\end{array}$ & 0.388 \\
\hline Clay & $\begin{array}{l}\mathrm{Y}=180.732+[(-294.994 * \mathrm{~B} 1)+( \\
652.717 * \mathrm{~B} 2)+\left(-603.214^{*} \mathrm{~B} 3\right)+( \\
146.468 * \mathrm{~B} 4)+(-49.077 * \mathrm{~B} 5)+(- \\
0.459 * \mathrm{~B} 6)+(120.344 * \mathrm{~B} 7)]\end{array}$ & 0.322 \\
\hline Silt & $\begin{array}{l}\mathrm{Y}=52.577+\left[\left(-192.838^{*} \mathrm{~B} 1\right)+(-\right. \\
103.168 * \mathrm{~B} 2)+\left(161.269^{*} \mathrm{~B} 3\right)+( \\
166.326 * \mathrm{~B} 4)+(34.155 * \mathrm{~B} 5)+(- \\
\left.0.187 * \mathrm{~B} 6)+\left(-36.18^{*} \mathrm{~B} 7\right)\right]\end{array}$ & 0.280 \\
\hline
\end{tabular}

The developed regression-based maps for surface soil properties $\mathrm{BD}, \mathrm{ADSMC}, \mathrm{Na}, \mathrm{CaSO}_{3}, \mathrm{P}, \mathrm{Fe}_{2} \mathrm{O}_{3}, \mathrm{CEC}, \mathrm{CaCO}_{3}$, Clay, and Silt were generated (see Fig. 4 and 5), and they have three advantages. The first that they show the spatial distribution of the focused surface soil prosperity. Second, they build up an updated spatial database of the studied soil property, while the third, provide an opportunity for monitoring changes that could happen with time.

\subsection{Mapping Accuracy}

Generally, spatial distribution of the predicted surface soil properties in all generated (predicted) maps mostly similar to their real distribution in the field. For instant, the laboratory-based estimated BD value in the soil sample of the site Kawanian- 6 was $\left(1.83 \mathrm{Mg} / \mathrm{m}^{3}\right)$, while predicted value in the same location at the predicted map was $\left(1.81 \mathrm{Mg} / \mathrm{m}^{3}\right)$. Additionally, the estimated BD value of the soil sample of the site (Andik-36) was $\left(1.82 \mathrm{Mg} / \mathrm{m}^{3}\right)$, whilst the value of predicted BD of the same site was (1.81 $\left.\mathrm{Mg} / \mathrm{m}^{3}\right)$. Table 3 shows the other locations with their estimated and predicted the studied surface soil properties, while Figs. 4 and 
5 show the predicted map of spatial distribution of the soil bulk density BD in the study area.

Table 3. The measured and predicted surface soil properties values of some study locations.

\begin{tabular}{l|lll}
\hline $\begin{array}{l}\text { Soil } \\
\text { Property }\end{array}$ & $\begin{array}{l}\text { Location } \\
\text { name }\end{array}$ & $\begin{array}{l}\text { Estimate } \\
\text { value }\end{array}$ & $\begin{array}{l}\text { Predicted } \\
\text { value }\end{array}$ \\
\hline \multirow{2}{*}{$\mathrm{ADSMC}$} & Bnaslawa-1 & 3.17 & 3.2 \\
\cline { 2 - 4 } & Soran-32 & 5.67 & 5.4 \\
\hline \multirow{2}{*}{$\mathrm{CaSO}_{4}$} & Dlopa-2 & 15.0 & 16.6 \\
\cline { 2 - 4 } & Razok-31 & 2.0 & 1.9 \\
\cline { 2 - 4 } & Mirawa-7 & 35.0 & 37.7 \\
\hline $\mathrm{P}$ & Solav-29 & 39.0 & 39.0 \\
\cline { 2 - 4 } & Kawanian-6 & 23.6 & 23.1 \\
\hline $\mathrm{Fe}_{2} \mathrm{O}_{3}$ & Goramark & 21.0 & 20.8 \\
\cline { 2 - 4 } & Palanyan-11 & 29.5 & 29.8 \\
\hline $\mathrm{CEC}$ & Goramark-28 & 36.5 & 37.8 \\
\cline { 2 - 4 } & Shekhan-27 & 28.4 & 28.5 \\
\hline $\mathrm{CaCO}_{3}$ & Sisana-8 & 28.6 & 29.3 \\
\cline { 2 - 4 } & Palanyan-11 & 475.0 & 475.1 \\
\hline Clay & Qadra-25 & 400.0 & 405.1 \\
\cline { 2 - 4 } & Razar-9 & 219.5 & 217.1 \\
\hline Silt & Bnaslawa-1 & 424.2 & 456.2 \\
\cline { 2 - 4 } & Degoden-23 & 298.5 & 443.5 \\
\hline
\end{tabular}

To calculate the statistical relationships between the surface soil estimated values and those the predicted values which we got them as a results of the regression equations and the predicted maps, the correlation analysis has been used with the aid of the SPSS. The results showed in general, there were significant positive correlations (see Table 4) between the estimated and the predicted surface soil properties.

\section{CONCLUSIONS}

In this study, the Landsat-7 ETM+ images data, field observations, laboratory analyses for chemical and physical surface soil properties, and statistical analyses were employed. The models generated may be generalizable to other similar sites in the region. Iraq has a vast land area with varying environmental conditions. As planning proceeds for increased agricultural production, the mountainous areas in the north including the Kurdistan region, the flatlands and wetlands in the south, the desert in the west, and the undulating lands in the east lack accurate soil maps. Remote sensing and associated techniques combined with a targeted field survey provide the data necessary to conduct a sufficiently detailed survey for the natural resources, including soils, enabling agricultural planning. Future work will extend these methods to other areas in the region and test higher spatial and spectral resolution sensors, new field methods, and advanced spatial models to refine the soil maps.
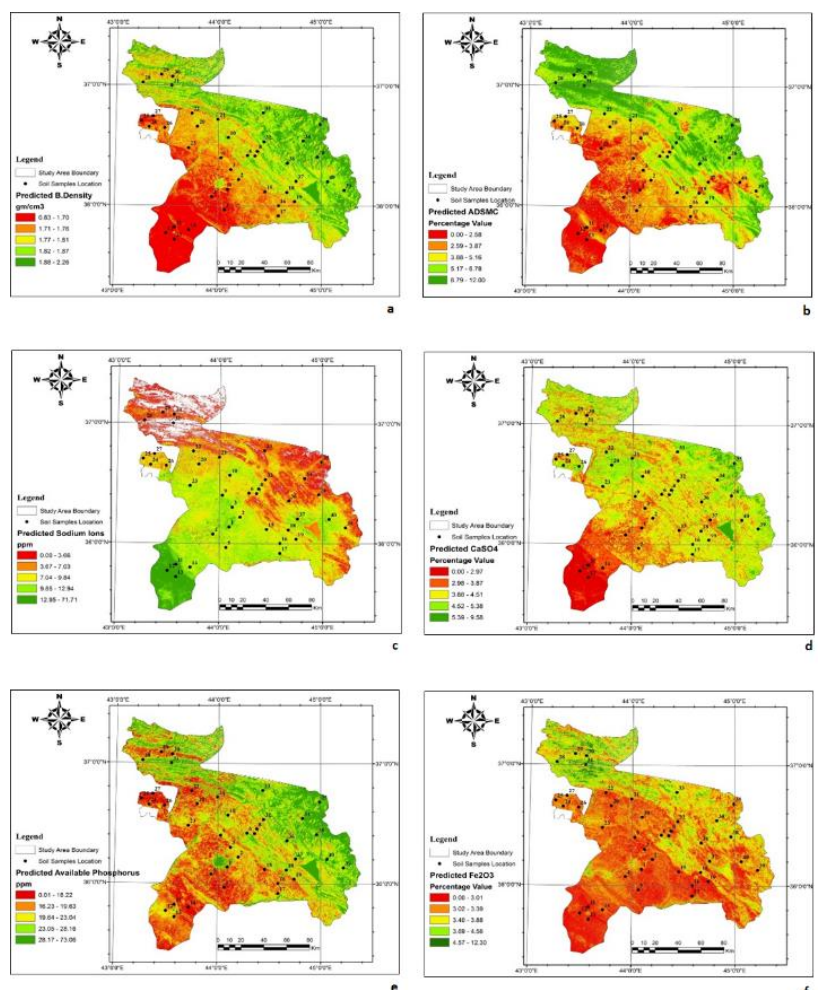

a: $\mathrm{BD}, \mathrm{b}: \mathrm{ADSMC}$, c: $\mathrm{Na}$, d: $\mathrm{CaSO}_{4}$, e: $\mathrm{P}, \mathrm{f:} \mathrm{FeO}_{3}$

Figure 4 . The regression-based maps of the spatial distribution of the studied surface soil properties
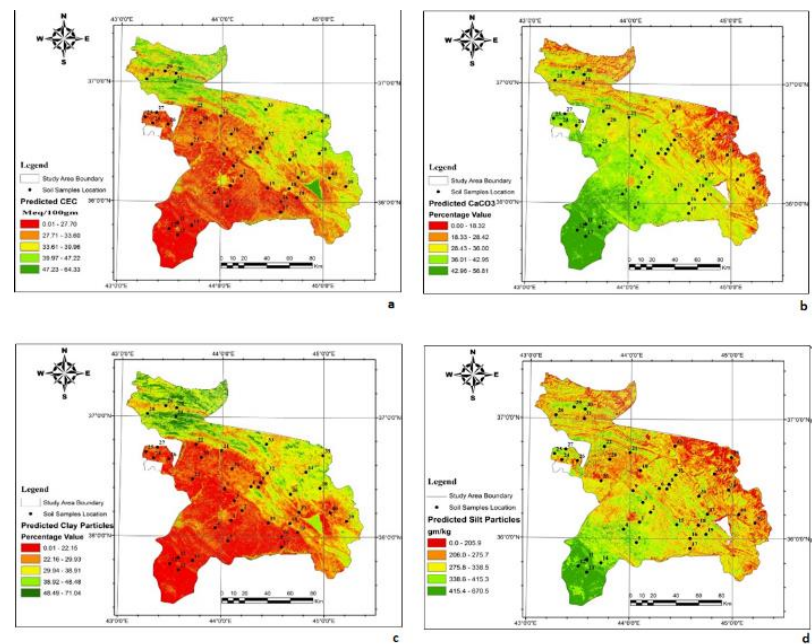

a: $\mathrm{CEC}$, b: $\mathrm{CaCO}_{3}$, c: Clay, d: Silt

Figure 5. The regression-based maps of the spatial distribution of the studied surface soil properties. 
Table 4. The correlation values between the estimated and predicted surface soil properties values.

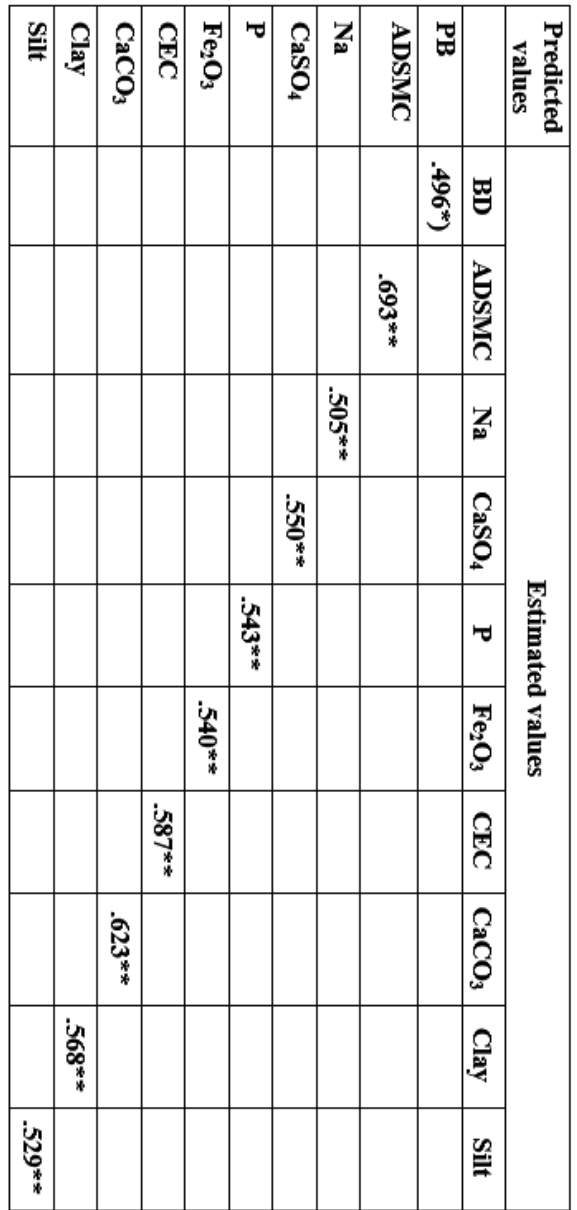

\section{ACKNOWLEDGEMENTS}

The authors would like to present their sincere thanks and gratitude to the Salahaddin University for offering the study aoopurtunity and to the Knowledge University, Erbil, Kurdistan region of Iraq for its valued financial support.

\section{REFERENCES}

Almamalachy, Y.S., Al-Quraishi, A.M.F., Moradkhani, H., 2019. Agricultural Drought Monitoring Over Iraq Utilizing MODIS Products. In: Al-Quraishi, A.M.F., Negm, A.M. (eds) Environmental Remote Sensing and GIS in Iraq, Springer (in press).

Al-Quraishi, A.M.F., Negm, A.M., 2019. Environmental Remote Sensing and GIS in Iraq. Springer Water, Springer (in press).

Al-Quraishi, A.M.F., Qader, S.H., Wu W., 2019. Drought Monitoring Using Spectral and Meteorological Based Indices Combination: A Case Study in the Iraqi Kurdistan Region. In: AlQuraishi, A.M.F., Negm, A.M. (eds) Environmental Remote Sensing and GIS in Iraq. Springer (in press).

Batjes, N.H., 1996. Total carbon and nitrogen in the soils of the world. Eur. J. Soil Sci., 47, 151-63.
Ben-Dor E., Banin, A., 1995. Near infrared analysis (NIRA) as a simultaneously method to evaluate spectral featureless constituents in soils. Soil Sci., 159, 259-269.

Ben-Dor, E., 2008. Imaging spectrometry for soil applications. Adv. Agron., 97, 321-392.

Bocchi, S., Castrignano, A., Fornaro, F., Maggiore, T., 2000. Application of factorial kriging for mapping soil variation at field scale. Eur. J. Agron., 13, 295-308.

Boettinger, J.L., Howell, D.W., Moore, A.C., Hartemink, A.E., Kienast-Brown S., 2010. In: Digital Soil Mapping, Bridging Research, Environmental Application, and Operation, Progress in Soil Science. Springer.

Bregt, A.K., Gesing, H.J., Alkasuma, M., 1992. Mapping the conditional probability of soil variables. Geoderma, 53, 15-29.

Brussaard, L., de Ruiter, P. C., Brown, G.G., 2007. Soil biodiversity for agricultural sustainability, Agric. Ecos. Envi., $121,233-244$

Cassman, K.G., 1999. Ecological intensification of cereal production systems: Yield potential, soil quality, and precision agriculture. Proc. Natl. Acad. Sci. USA, 96, 5952-5959.

Dobos, E., Montanarella, L., Nègre, T., Micheli, E., 2001. A regional scale soil mapping approach using integrated AVHRR and DEM data. Int. J. Appl. Earth Observ. and Geoinform., 3(1), $30-42$.

Fadhil, A.M., 2009. Land Degradation Detection Using GeoInformation Technology for Some Sites in Iraq. Journal of AlNahrain University-Science, 12(3), 94-108.

Fadhil, A.M., 2011. Drought Mapping Using Geo-information Technology for Some Sites in the Iraqi Kurdistan Region. Int. Journal of Digital Earth, Vol, 4(3), 239-257.

Fadhil, A.M., 2013. Sand Dunes Monitoring Using Remote Sensing and GIS Techniques for Some Sites in Iraq. In: Proceedings SPIE 8762, PIAGENG 2013: Intelligent Information, Control, and Communication Technology for Agricultural Engineering, 876206. doi.org/10.1117/12.2019735

Gee, G.W.,, Bauder, J.W., 1986. Particle-size analysis. In Methods of soil analysis. Part 1, 2nd ed., A. Klute, Ed., Agron. Monogr. 9. ASA and SSSA, Madison, WI, USA, 383-411.

Guyot, J.L., Filizola, N., Quintanilla, J., Cortez, J., Dissolved 1996. Solids and suspended sediment yields in the Rio Madeira basin, from the Bolivian Andes to the Amazon. Erosion and sediment yield: global and regional perspectives. - Proceedings of the Exeter Symposium «Erosion and Sediment Yield: global and regional perspectives 15.-19.7, Exeter, IAHS Publications, Exeter, 55-63.

Hameed M.H., 2013. Water harvesting in Erbil Governorate, Kurdistan region, Iraq, MSC thesis. Lund University.

Henderson, T.L., Baumgardner, M.F., Franzmeier, D.P., Stott, D.E., Coster, D.C., 1992. High dimensional reflectance analysis of soil organic matter. Soil Sci. Soc. Am. J., 56, 865-872.

Hengl, T., Gerard, H., Kempen, B.M., Johan, L., Walsh, G. B., Shepherd, K.D., 2015. Mapping soil properties of Africa at 250 
m resolution: Random Forests significantly improve current predictions. PLoS ONE, 10(6), e0125814 EPdoi:10.1371/journal.pone.0125814 PMID: 26110833.

Horvath, E.H., Post, D.F., Kelsey, J.B., 1984. The relationships of Landsat Digital Data to the Properties of Arizona Rangeland. Soil Sci. Soc. Amer. J., 48, 1331-1334.

Jensen, J.R., 1996. Introductory Digital Image Processing: A Remote Sensing Perspective, $2^{\text {nd }}$ Edition. New Jersey, USA, Prentice Hall.

Karlen, D. L., Mausbach, J. W., Doran, R. G., Cline, R. F., Harris, G. E., 1997. Soil Quality: A Concept, Definition, and Framework for Evaluation, Soil Sci. Soc. Am. J., 61, 4-10.

King, C., Baghdadi, N., Lecomte, V., Cerdan, O. 2005. The application of remote sensing data to monitoring and modelling of soil erosion. Catena, 62, 79-93.

Li, Z., Zhu, Q., Gold, C., 2005. Digital terrain modeling principles and methodology. CRC Press. Boca Raton.

Liu, W., Baret, F., Gu, X., Zhang, B., Tong, Q., Zheng, L., 2003. Evaluation of methods for soil surface moisture estimation from reflectance data, Int. J. remote sensing, 2003, 24(10), 2069-2083.

Lopez-Granados, F., Jurado-Exposito, M., Atenciano, S., Garcia Ferrer, A., Sanchez de la Orden, M., Garcia-Torres, L., 2002. Spatial variability of agricultural soil parameters in southern Spain. Plant Soil, 246, 97-105.

Madeira Netto, J.S., 1996. Spectral reflectance properties of soils, Photo Interpret., 34, 59-70.

McBratney, A.B., Minasny, B., MacMillan, R.A., Carré F., 2011. Digital Soil Mapping. In: Li H, Sumner ME, editors. Handbook of Soil Science. vol. 37. CRC Press, 1-45.

Montgomery, O.L., 1976. An investigation of the relationship between spectral reflectance and the chemical, physical and genetic characteristics of soils. $\mathrm{PhD}$ Dissertation, Purdue University, West Lafayette, Indiana. Univ. Microfilms.

Mulder, V.L., Bruin, S. de, Schaepman, M.E., Mayr, T.R., 2011. The use of remote sensing in soil and terrain mapping-A review. Geoderma, 162(1), 1-19.

Mustafa, B.M., Al-Quraishi, A.M.F., Gholizadeh, A., Saberioon, M., 2019. Proximal Soil Sensing for Soil Monitoring. In: Al-Quraishi, A.M.F., Negm, A.M. (eds.) Environmental Remote Sensing and GIS in Iraq, Springer (in press).

Nanni, M.R., Demattê, J.A.M., 2006. Spectral reflectance methodology in comparison to traditional soil analysis, Soil Sci. Soc. Am. J., 70(2), 393-407.

NRC (National Research Council), 1997. Precision Agriculture in the $21^{\text {st }}$ Century. National Academy Press, Washington, DC, 149.

Paz-Gonzalez, A., Taboada-Castro, M.T., Vieira, S.R., 2001. Geostatistical analysis of heavy metals in a one-hectare plot under natural vegetation in a serpentine area. Can. J. Soil Sci., 81, 469479.
Schulze, D.G., Nagel, J.L., Van Scoyoc, G.E., Henderson, T.L., Baumgardner, M.F., Stott, D.E., 1993. Significance of organic matter in determining soil colors. In: Bigham, J.M., Ciolkosz, E.J. (Eds.), Soil Color. SSSA Spec. Publ. 31 SSSA, Madison, WI, 7190.

Slaymaker, O., 2001. The role of remote sensing in geomorphology and terrain analysis in the Canadian Cordillera. Int. J. Appl. Earth Obs. Geoinf., 3(1), 7.

Stoner, E.R., Baumgardner, M.F., 1981. Characteristic variations in reflectance of surface soils. Soil Sci. Soc. Am. J., 45, 11611165 .

Wu W., Muhaimeed A.S., Al-Shafie A.M., Al-Quraishi A.M.F., 2019. Using Radar and Optical Data for Soil Salinity Modeling and Mapping in Central Iraq. In: Al-Quraishi AMF, Negm AM (eds.) Environmental Remote Sensing and GIS in Iraq, Springer (in press).

Wu, W., Zucca, C., Muhaimeed, A.S., Al-Shafie, W.M., AlQuraishi, A.M.F., Nangia, V., Zhu, M., and Liu, G., 2018. Soil Salinity Prediction and Mapping by Machine Learning Regression in Central Mesopotamia, Iraq. Land Degradation and Development, Wiley, Vol, 29, 11, 4005-4014. doi.org/10.1002/ldr.3148 